\title{
茶苗根腐病に関与る研究（第2 報)
}

\author{
農林省東海近戴農業試験場茶業部 笠 并 久三
}

全国の主要茶樹械培府県のさし木苗床仅発生する苗根 病の被害根部加ら Pythium 属菌の分離を行なつてい るが，特に，静岡県・三重県和よび鹿览県のものについ て病原蓀の形態・生理・病原性・所属などを調䍒した。

静岡菌は分性胞子捛よび卵胞子を形成する。蔵㥸器は 多数の剛刺状突起を有する。本菌はじやがいも顛汁寒天

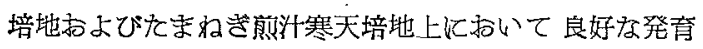

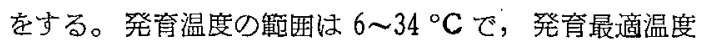
は 26 ○C 附近である。

三重菌は游走子のう拉よび卵胞子を形成する。本菌は

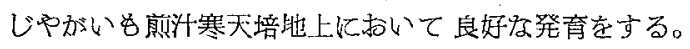
発育温度の䈟国は $6 \sim 33^{\circ} \mathrm{C}$ で, 発育最適温度流 $26^{\circ} \mathrm{C}$ 附近である。

鹿児島菌は分生胞子を形成する。本菌はじやがいも煎 汁寒天培地上に扬いて良好な発育をする。発育温度の筑 斗は $8 \sim 34^{\circ} \mathrm{C}$ で，発青最適温度は $26^{\circ} \mathrm{C}$ 附近である。

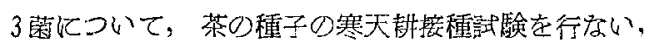

病原性の強さを語査した結果, 静岡菌, 鹿児島菌, 三重 菌の順位であつた。

静岡菌梳活将 Pythium spinosum と推定された。三 重菌, 度児島菌䏓いては, さらに調查を行なう予定で ある。

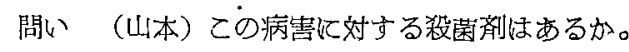

答え クロールピクリン，ベーパム衣どがある。 東海化成のアセトールは末発表であるが，林業の 杉の苗床で使われ，茶でもきく。

問い（山本）オーソサイドがテンサイにきくが，茶 ではどうか。

答光 かなりきくようである。

問い (牛島) 根磨病は成木睘でも起こるか。

答无 立枯性病害のなか淀状の似ているすのも西る 加ら，本菌は成木をも侵害すると思われる。この 防除試験は現在まで行なつていない。

\section{茶樹の根腐れを原因する Fusarium 属} 菌について

京都附立大学農学部 安 倍 卓爾 - 高日幸 義

春から秋汇かけて茶街す生育が衰えて 荎葉が黃褐色を

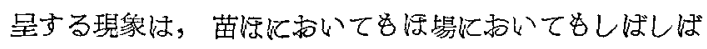
認められるところであるが，乙のようなものを風り起こ して根部を検すると，先端部の細根が鹰朽し，やや太い 根も黑褐色湿潤状を呈して枯死していることが認めら れ，分離試験の結果はていてい Fusarium 属苗が得られ

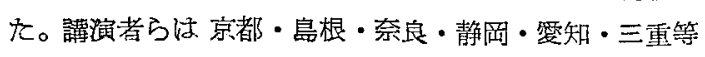

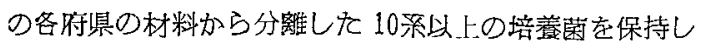
ているが，その中 $\mathrm{F}_{1}$ (京都府睤山)， $\mathrm{F}_{2} \mathrm{a}, \mathrm{F}_{2} \mathrm{~b}$ (島根 罧出密市)， $F_{3}$ (静岡県金谷), $F_{4}$ (宗都府城陽町), $F_{5}$ (奈良県波多野)の6分離系沉ついては菌の形態，培盖 上の諸性質その他について一忘の笑験を行なつたので， ここにその結果の一部を竱告することにした。

てれらの培恙系統は菌系, 分生胞子および厚膜胞子な

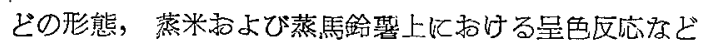
加ら Fusarium 属のもの之楒められるが，その中 $\mathrm{F}_{1}$ は
Section Arthrosporiella 亿また $\mathrm{F}_{2} \mathrm{a} \sim \mathrm{F}_{4}$ 注多少の善は あるがいずれも Section Elegans 亿彷入るものと見なさ れる。F 5 についてはな和測定不十分のため所属区を決定 し難い。

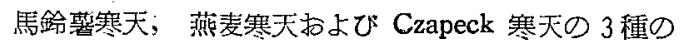

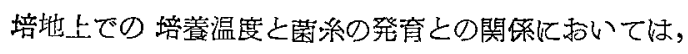
最低温度が $-2 \sim 4{ }^{\circ} \mathrm{C}$, 適温 $20 \sim 24^{\circ} \mathrm{C}$, 高温限界が $32 \sim$ $36^{\circ} \mathrm{C}$ 亿ある $\mathrm{F}_{1}$, 最低温度が $-2 \sim 4{ }^{\circ} \mathrm{C}$, 適温 $26 \sim 28^{\circ} \mathrm{C}$ 高温限界が $36 \sim 40^{\circ} \mathrm{C}$ 江方 $\mathrm{F}_{2} \mathrm{a}, \quad \mathrm{F}_{2} \mathrm{~b}, \mathrm{~F}_{3}, \mathrm{~F}_{4}$ の群 之, 最低発育温度吕 $9 \sim 16^{\circ} \mathrm{C}$, 適温 $28^{\circ} \mathrm{C}$, 高温限界か 36〜40 ${ }^{\circ} \mathrm{C}$ 汇ある3つの群化分けられた。

馬敛瑟寒天扰よびCzapeck 寒天の 2 種の培地を用いて

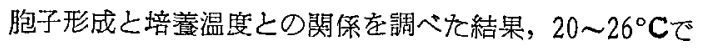
厚膜胞子を形成し， $28^{\circ} \mathrm{C}$ でずか似分性胞子を形成す る $\mathrm{F}_{1}, \quad 16 \sim 32^{\circ} \mathrm{C}$ で分性胞子を形成しその適温が 24 $26^{\circ} \mathrm{C}$ 飞ある $\mathrm{F}_{2} \mathrm{a}, \mathrm{F}_{2} \mathrm{~b}, \mathrm{~F}_{3}, \mathrm{~F}_{4}$ の群と，いずれの温度 
でも全く胞子を形成しない $\mathrm{F}_{5}$ とのう群に分けられた。

馬敛整寒天 - 燕麦寒天 - 人參 - 乾杏寒天 - Czapeck 寒 天・茶葉寒天・苲米の 7 種の培地を用いて, 培地の種類 和よび培着日数と胞子形成との関係を見る之，乾杏寒天 および蒸米以外で厚膜胞子のみを作る $\mathrm{F}_{1}$ ，多少の差はあ るが各培地上で分生胞子を形成する $\mathrm{F}_{2} \mathrm{a}, \mathrm{F}_{2} \mathrm{~b}, \mathrm{~F}_{3}$ 招よ び $\mathrm{F}_{4}$ の群と，燕麦寒天上でわずか纪分生胞子を形成す る $\mathrm{F}_{5}$ との3群汇分けられた。

1 年生苗について葉・成茎・若茎・成根括よび新根の

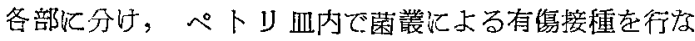
い，10日打よび15 日後の観祭によつて柔統間の病原性䒚 比校した。それによると病原性は $\mathrm{F}_{2} \mathrm{a}$ 最も強く, $\mathrm{F}_{3}$, $\mathrm{F}_{4}, \mathrm{~F}_{2} \mathrm{~b}$ と順次乙れに次ぎ， $\mathrm{F}_{1}$ お。び $\mathrm{F}_{5}$ では非常に弱

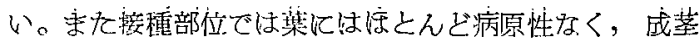
和よび成根に対しても強い病原性を示さないが，新根抲 よび新荎に涊いずれもかなり強い病原性を示した。

次に 実生苗を用いて根の先端部に接種した結果による と， 1 年生苗の場合上㴽ほ同梯の成績であり，有稘接種

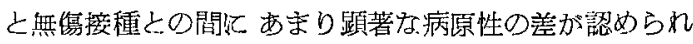
なかつた。

なおクロールピクリン,: ホルドウ液，ルベロン，リオ

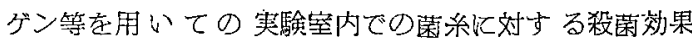
は，クロールピクリン最も溞く，4-4 式ボルドウ淮こ れ《次ざ，他の 2 者には明らかな盖異が認められなかつ た。

\section{合成飼料によるコカクモンハマキの 無菌飼育}

農林省東海近畿譨業試験場茶業部 玉 木 佳 男

ダルコース・カタイン・乾燥酵母・コリンクロライド ・無機塩・セルロース・寒天尔よび 茶葉粉末加らなる合 成飼料によつてコカクモンハマキ幼虫を無䒩的汇慨育す ることに成功し，ての方法を用いてコカクモンハマキの 発育にたいする飼料中の茶葉粉末の効果を検討した。

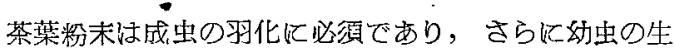
育を著しく促進する效果をもつ。すなるちち茶葉粉末中に は末知の発育因子が存在すると考えられ，その最適含量

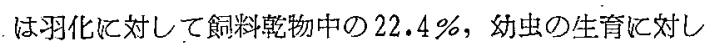
て17.8 22.4\%であつた。
茶葉炇末の簡単な化学的分割の結果，乙れらの羽化効 果ならびに生育効果は，それぞれ別の因子炕よるもので あり，成虫の羽化汇必須の因子は温湯不溶性であるに反 し，幼虫の生育を促進する因子は温湯可溶，エーテル不 溶性の物質であると考えられる。

この講演は南川傅が代演した。

希望（山本，大島）たい几ん和畐しろい問題である 加ら, 大いに研究を進めてはしい。

\section{チャハダニの防除時期について}

嶄林省東海近畿農業試験埸茶菜部刑部勝

チャハダニを防除するにあたつて，乙こ数年来早春の 楽剤散布が有効であるとして推獎されてきたが，今回晚 秋散布も一番茶の名二を抑制するうえに，“予想以上儿效:

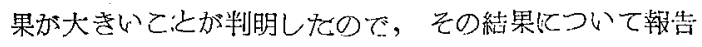
する。

すなわち，1958年11月から59年3月にわたつて，每月 1 回, 同一同丧度の楽剤(トリチオン乳風 1000 倍) を散 布し, 定期的飞八ダ二の密度調べた結果, 発第期汇抽 けるハダニの密度は 11，12月散布区が最低で，試験全期 間を通じて他のいすれの月の散布よりも良好で放つた。
一方，3月散布区の効果が意外纪ふるわず，2月散布 の效果より劣つたが，乙れ的 2 月の㸚温が例年より高く 3 月上旬散有では 八ダニの痤率開始以後であつたのが最 大の原因上考流れる。

今後はさら飞脕秋散布と早春散布之の組合せ，睌秋散

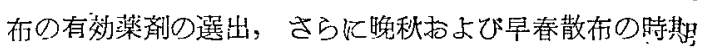
と效温との関係などに゚ついて検討したいと考えてい る。

この講演抙南川仁博が代演した。 


\title{
クワカイガラムシ成虫に対する \\ 殺虫剤の效力について
}

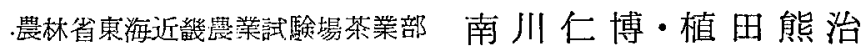

クロカイガラムシ成出は散有薬郕に対し抵抗力がきわ めて強いので，成虫期つ散布楽剂効果を知るためと，冬

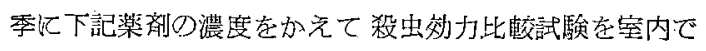
行なつた。

ドルマント乳剂, フッンール, ヤノネックス乳剤, DNマシン油乳阂, カワソ゚ール乳剂各 100, 200 唐, マシ ン油乳剂 40，60倍，アルポ油 20，50咅，石灭硫黄合成 15, 20咅。

試駼は11〜 4月に8回行ない，3区制で各50頭化つい て生死を調べた。

この試験で特にすぐれた成績を収めたのはドルマント 乳剂とフッンールであつたが, 試験のたび効果の変動 が大きく，防除效果化大きな期待は持てなかつた。この
夜動の原因については今後追究の予定である。

ドルマント，フッソール 各 100 倍と石可硫熼会剂15倍 の殺蚛力は次のようである。

8 回の試験中 ドルマント乳剂は殺虫效力 $40 \%$ 以上が 4 回西つて，5 590，60，50，40\%殺虫効力が各 1 回あつ た。フッソールは40\%以、上の効果が 2 回あつて，70；50 \%効力が各1回のみであつた。

ヤノネックス乳鼡, DNマシン油乳剤, カロゾール乳

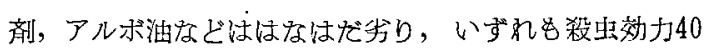
\%以下で, 杂たマシン油乳剤の 40，60倍は全く殺虫効力 は認められなかつた。次に各薬剤の濃 度間で 100 倍と 200 倍は殺虫効力化大差はみられねかつた。

\section{茶園経営の改善について \\ (III) 優良品種の導入による経営改善}

\author{
京都府宁㖘雷茶策課 水山登 \\ 宇治農業改良普及所 佐 藤 隆 夫
}

優息品種茶圆の生産性を明引かにし 品種茶園の普及に

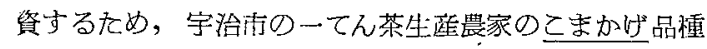
圆之在来实生園の生産性䎲ついて.比校調查を行なつた結

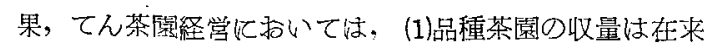
実生茶圆（成園）水比し定植 6 年目（被賈第 1 年）で $48.2 \%(10 \mathrm{a}$ 当たり茶 $63.250 \mathrm{k}$ )，7年目(被覆策 2 年) $83.8 \%$ (同 $114.000 \mathrm{k}$ )，8年目（被覆第３年） $101.1 \%$ （同 $126.000 \mathrm{k}$ ) で，在来実生園の收量比追いつき（2)品 質（茶の洒格）では被覆第 1 年目ですでに在来帮生茶の

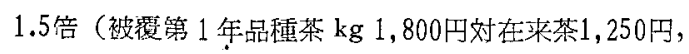
第 2 年同 2,000 月奶同 1,111 円，第 3 年同 2,080 円 对同 1,400円) 飞近い価格で取引きされた。(3)粗収入(10 a 当たり)では定植 6 年目（被㴗策 1 年）で $69.4 \%$ (品種 園 113,800円《对し在来園 164,000円)，7年目（被覆第 2 年目で 228,000 月対 151,200 月)，8 年目(被覆第 3 年 目で262,000円奶 174,300 円）ともに $150 \%$ で，7年目 ですでに在来実生猿の 1.5 倍汇達し，その開きは品質 (洒格)の善によるサのであつた。
また被灌第 2 年目（定植 7 年目）のこまかげ園と在来

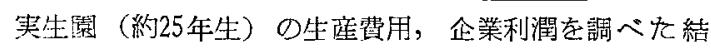
果, (4)単位面積当たりの生産費用では，収量差による摘 採費（品種㕑15,707円対在来実生園18,137円），製造費 同26,520円対同 31,110円)のわずかの美にとどまり（10 $a$ 当たり品種園 121,212 円対在来実生園 128,262 円),

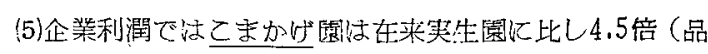

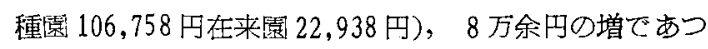
た。

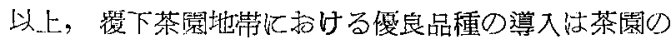

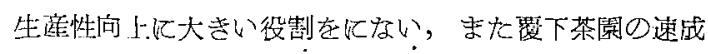
にも役立つことが明らかとなつた。

問い（前原）品種溒の澍令は何年か。

答え 胎和33年で 7 年生であるが，生育は特仙よい低 うである。

閵い（前㹉）栽植方法恃どうか。

答光 昭利 26 年に 2 年生苗を $1.8 \mathrm{~m} \times 0.3 \mathrm{~m}$ 植えた。 


\section{暖地にお泣る玉露園の摘採回数 \\ について}

農林省九州農業呵験場作物算一部

山村方正・松岡恒雄 - 池田三郎

九州の平坦眼地では，肥培が十分に行なわれ，しかも

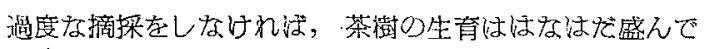
特に肥培の周到方露京ではこの傾问がさらに大きい。

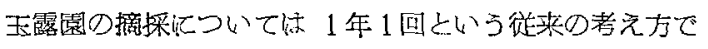
は，摘採，せ九校後の生育が盛んなため，新梢は70 $80 \mathrm{~cm}$ 飞も及び, 䍿年の摘採特には新芽の項部は地上 180 $\sim 200 \mathrm{~cm}$ 亿名及心。

玉露園としての拾指いの高さ仅は限度があり，このよ うな茶樹の生育では一般に行なるれている180〜200 cm

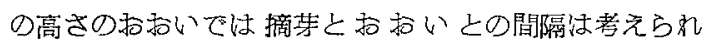

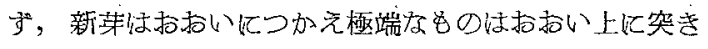
出る。乙礼惊葉の品賀, 収量を垈下しまた摘榇能率を 低下寸る。乙れらを解決する一つの方法として, 摘採回 数を增加することによつて 罚高をある程度規正すること を試みた。

一番茶のみの摘採区を $\mathrm{A} ， 一 \cdot$ 二番茶までの摘採区を $\mathrm{B}, 一$ 二・三舀茶まての摘採区をCとし，次の項目に ついて調查した。

(1) $900 \mathrm{~cm}^{2}$ 内芽数, 同芽重, 芽骎, 百芽望, 開琵数。

(2) 收量。(3) 菜の品留。

この結果, 試験開始 2 年間は各調查項目と8年変動が はなはだ大きく摘採回数による桨化は認め引れないが， 3 年目ごろから穴化が現われ礼じめている。

(1)の調査賢目以それぞれ年による変動㥗あるが，A区 の変動が最も少なく， B 区は最も大きな変動を示してい る。C区は比較的変動は少ない。乙れを総括してみると

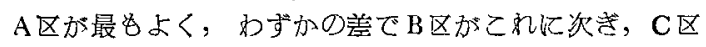

は最为劣つている。

収最については备区とも年でとの後動は大きいが，同 じような傾问を示している。収量の通年の平均をみると

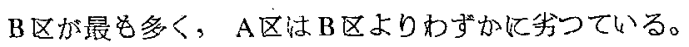
C区はA，B両区比しはなは忧しく少つている。

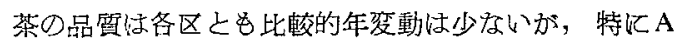
区の変動が少なく，安定している。 $\mathrm{B} ， \mathrm{C}$ 車区は $\mathrm{A} 区 に$

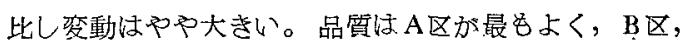
C区の順となつている。

以上を総合してみると，玉露邀の摘採は一番茶のみの 摘採が最もよいこ上は明らかで西るが，二番茶きで摘採 しても，一番茶の办㓓採区に比し多少劣る傾向はある が，西る程度樹高の制限ができ，したがつて据採能率あ るいは被覆の高さ等から考衹て，九州の平坦䁔地では二 菒茶まで摘探しても，一番茶のみの摘採のものと比較し

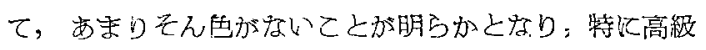
ね无露でなければ，二番茶なで摘採してもさしつかえな い。しかし三番茶まで摘埰することは晶質・仪量学低下 するため，三番茶までの摘採恃すべきではない。

問い（渡辺）上性がよい上二番茶まで摘んでも增仪 になり，悪いと減収になると思うが，乙れ関す る研究林か。

答えやつていない。

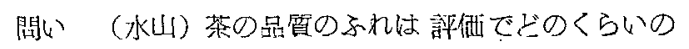
羑になるか。

答气 評価はしてないが今後はやりたい。

\section{茶芽の熟度とかまいり茶の品質 について}

管崳県濃檏試験堨川南分埸鮫島斎・黑木史郎

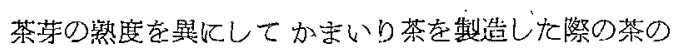
品質の差異につき試駧する目的定もつて，昭和34年春茶 期飞10品種を供用し，発芽期直後から出開度 $90 \%$ まで摘

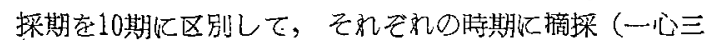

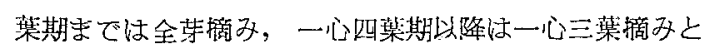
した）ならび结まいり茶を製浩して試験した。熟度と

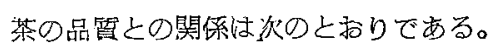

1. 剧状：一心一葉期加ら一心四葉期までは成形が筞 朚であるが，熟度が一心五葉以上に進もと䋨り悪く研菜 疦が目立ち急速に㽎状が悪くなる傾问がはつきりした。

2. 色沢：色沢は品種ならびに熹度によつて翼なる が，一般に若牙のものは黄悢のさえた色沢を持ち, ピン 
ローチェン，ロンチン等に類似する。熟度が進むにつれ て一心四葉，一心五箱期灶鮮綠であるが，さらに热度が 進しでくると線褐色となる傾向がはつきりした。な和若 芽のものは変色しやすく，アメ色を帯びる䝨向も見受け られた。

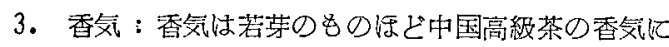
近くきわめて良好であるが，熟度の推むにつれだんだん 低くなり，一心四葉期を境いとして芽の香気はうすれて 葉の臭味が強く出てくる傾向がはつきりした。

4. 水色: 一心三葉ないし一心四葉期まてい水色は赤 橙味を带びるが，一心五葉期を境いとして以後は爆色 系の水色となる。さらに熟度功進んでくると黄色系の色 調となる傾向が非常にはつきりした。一心四葉期までの

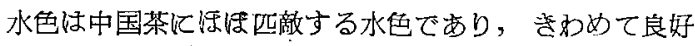
であつた。

5. 滋味・一心二葉期までは苦橴味が二般治いが， 一心三葉期以降㳉蓄味が少なくなる傾向である。全体的 に若芽のもの恬ど味が強くコクがある。出開度 80 90\% では味には压とんどコクがなく、いかゆる軽い茶となる。 熟度と収量との笑係で，収量は熟度の進むにつれ一
心五葉期までは明らか汇急速に增大してゆくが，出開度 50\%期から80\%期までは収量恃恃とんど庐行に近いゆる や汃增大曲線となる。しかし出開度 $90 \%$ 期汇はまを急 激に上帠曲線を描くに至ることがはつきりした。

以上の収量と茶の品啠との関的を総合して考察すれ ば，一心一葉期加ら一心五葉期までは収量增大は喼激で 西るが品質の低下注比較的功るやかである。しかし出開 度 $50 \%$ 降では収量增大は活とんどないが，品質の劣要 化林熟登の進むにつれて非常に急速である。かまいり茶

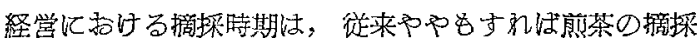
摘期をそのまま不用意に加いり茶にあてはめている か，あるいはそれより和そい時期がむしるよいとする考 えケが方つたが再検討の心要が西るものと思われる。

よつてかまいり茶の品質问上を意図する経営では，そ の摘採の熟度は抬そくも一心五葉期摘採までを限度とし て，乙礼以前の，すなわち一心四葉期前後の若芽を摘探 する場面で経営のあり方考える必要があるう。

闆い（吉田）摘採したのは何時でろか。

答え 午前中である。

\section{ビニル被覆による無かん水 さし木法について (予報)}

福岡県立厜策試験場䒩業指導所 桐明政美 - 坂田寿生

茶のさし木の慣行では 発根まで棌とんど每日かん水を 要し, 水不足の所でのさし木はなかなか困鞋とされてい た。農家ではこの時期は特化多忙で十分なかん水ができ す，さし木の惕も自然住居の近く㳊置していた。そ こで発根までのかん水だけです省くことができたなら

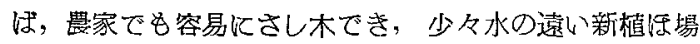
にでもさし床を作ることができ，そうなれれは優泉品種の 新楅, 改植も早いと考沉れる。

ビニル被覆による無かれ水さし木は桑のさし木におい て33年度仪試験の結果，発根まで無か儿水にて良好な成 績をあげていることを知り，本県農䟼亘業部の助言を得 て予備的䏓調查をした。

さし林は東西うねとし，さし木後十分かん水し，農業 用なし地 (不透気性) ビニルで括和い，内部を外気とし や断する。ささらに淔射日光を防ぐためむぎららで和放い をする。

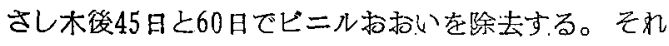
まではかん水その他の管理は行なかず，日括放いはビニ ル除去後も絸け，その後の管理は常法により6月さしと
8月さしで調查した。

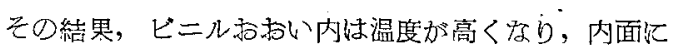
水滴李附盲し，これ在伝わつて床面に流れ落ち、ビニル 除去時でもさし床は適度の水分考保つている。

1）発根㤬活と儿ど地ぎわからが多く，6月ざしでは 根数・根重はよいが，根長では対照区がよい。8月さし で根の状態は全般に対照区がよい。

2）活着率㤬94〜98\%で対嵒区よりよく，特に8 月さ しでは臸がある。

3）新梢の伸びは奶照区との差は怯つきりし，8月さ しでとくによい。着菑が少なく発芽がよい。

4）ビニル除去はすし木㣪45日より60日がよかつた。

てのこと加無汃儿水にて発根することの可能性忖認 められるので, ビニル除去の時期, 根の保磪, その他実 用空用化についてさらに調查を進めてい。

問い（穂村）黃化穂とは何か。

答え 黃化穂は九州晨碔加らもらつたものであるが， やや軟弱であつた。 
問い（㯖村）現在はどうなつているか。

答え 6月さしは防寒の和打いだけしている。8月さ しはビニルで保温している。

問い（锶村）モグラの害はないか。

答え B HCを散布して 12〜15 cm の深さに打ち込む とよいと聞いている。

問い (曼額) ビニルの寔さと色は何か。

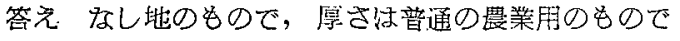
ある。
悶（塘）苗床は赤士でなく黑土でもよいか。片屋 根でもよいか。

答え 床土は赤土老使つている。片屋根はやつていな 4。

問い（牛島）発根が指ぎかであるのは水分が過剩の ためではねいか。

答え 普通さしで姁口から発根するが，このさし木 法では地中の室気不足と過湿のため，地ぎわ発根 が多く切口は度つている。

\title{
黄化さし木法の実用化 \\ 肥料とジベレリンの組合せ
}

\author{
農林省九州農業㔀験場作物第 1 部 讃 并 元・安 間 舜
}

鱼化処理さし木法によればきわめて発根が早いため,

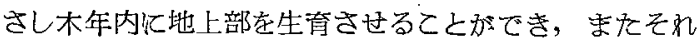
によつて地下部も著しく充実するてとはすで報告した

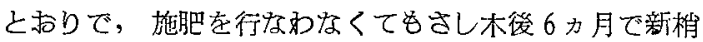
$11.0 \mathrm{~cm}$ ，葉数 9.4 となり，根量は謴行法 015 力月目飞匹 敵する。前韩比和いて第 1 回の根群形成後加马施肥在行 なえばさらに生育は促進され，装春には定植可能苗とな ることを明らかにした。

さらにさし木年内の生育を促進すれば，健苗を 5 〜 カ月で蒦得できるものと考え，短期育苗を目票として黃 化好理をでき得る限り早く行ない，施肥とジベレリンの 効果について実験した。

その結果, さし木䒺 4 力月の拥取り調查では，地上部 は標準肥料 (N. $37.5 \mathrm{~g}$, P. $12.3 \mathrm{~g} ， \mathrm{~K} 12.3 \mathrm{~g}$ 成分量 $3.3 \mathrm{~m}^{2}$ 当たり）+ジベレリン区がまさり，地下部は多肥 ナジベレリン区がすぐれていた。その後の地上部の牛育 は䧣準肥料+ジベレリン区の生育きわめて著しく，さし 木年度の11月にすでに新梢長 $20 \mathrm{~cm}$ に達した。
この結果から，黃化さし木を 5 月に行ない，1 月月後 から漂準肥料を施し， ジヘレリン $10 \mathrm{ppm}$ を 2 週間じと に散布すれ社，さし木後 6 力月で樹离 $25 \mathrm{~cm}$ 以上の健苗 を隻得できることが明らかとなつた。

間い（植垣）黃化夗理は畑でやるのか。

答え 畑で 6 週間行なう。

問い (植亘) 空内几持つてきてやつたので灿いけな いか。栄盖分在可給態枋するが目的ではねいか。 答え 期間が短くてはだめである。

問い（植垣）ジベレリンはいつ敬布するのか。

答えさし木1カ月後から15日拉に筆で叙つた。

閆い（植垣）根が伸びるか。

管元 根も伸びる。

間い(简橋) ジベレリンによるさし穂の切口浸清は していないか。

答えしていねい。

\section{暖地における茶樹の寒害に関する研究}

（第1 報）主幹小よび枝条の寒害

鹿児島県茶業試験場·泊純・岡村克郎・岡本信義

鹿児島県下の紅茶奶木㝨に妨いて，主幹や枝条の寒害 が生じたので，その被書調査と防除法につき試験した。

主幹・枝条寒害の特徵：被害は主に 1 2 年生, まれ

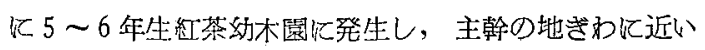
部分や，枝条汇被㕩をらけ，この部分の皮層: 節部抬々 び形成䐄を含む絽織が損傷，裀恋し，遂にはこの部分に 


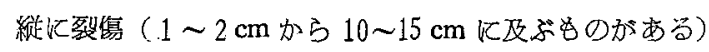
を生ずるものが多い。乙の被害注主幹や枝条の全周仁更 ぶものと，その一方位のみに受ける塲合があるが，被害 部位から上位の葉（一方位のみの被害のとをはその同方 位の上位葉）法次第江光沢を失い, 青枯れの状態となり，

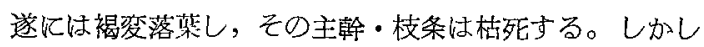
生存的地下部比いて続けられ，3４月加ら $5 \sim 6$ 月 になつて再発芽するものが多いが，中には全く枯死する ものもある。被管相が現われる期間は，寒害㷋早ければ 1 週間前後, おるいとさ 5〜6月になつて現われるこ とがある。早く被篦の現われるものは一般に茎の全周に 寒箅を受けたものであり，緩膘に現われるものは，蕉の 一部汇寒㫪を受けたもので，軽い被㫪で忏新芽结生充す るが短く，2～3葉で出開く頋问加㘯る。

この寒害は一般飞樹令の若い菜園に多く，はつも观じ 2 年生の $7.7 \%$ 被管率纪奶し，1年生话 $88.3 \%$ ですつ た。また 2 年生汇ついて羽ると被害株は無被害株飞対 し, 裾上りとなつて地上 $15 \sim 20 \mathrm{~cm}$ 注分枝がねく主幹が 露出してて，低温にさらされているものであつた。ま主 幹の裂傷方位をはつも两し 1 年生で調查すると，日出方 位の東南面, 南面抽よび西面比多く, 北面, 北東面はき わめて少ない。

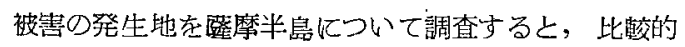
寒䁔の善の大きい平坦合地の紅茶園飞多く, 海岸沿いの 暖地にはその例なく，山手山間部认汸比较的少ない䐜向 がある。

防除詞験：寒害を受け裂傷を生してて茶株に対し，12月
上旬土寄せを行ない無好理区と比䓉すると，土寄せ区で

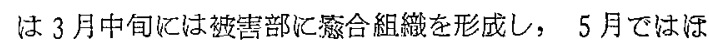
とんど洽痖し無被害区と変らなくなるが，無処琹区は 5

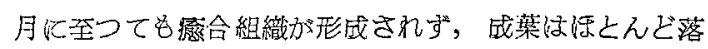

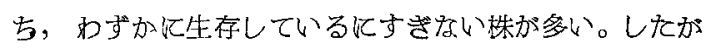
つて被霓株は土寄せ炕よつてその被害を軽減させること ができるといえよう。

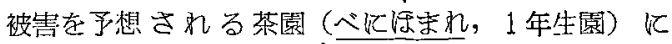

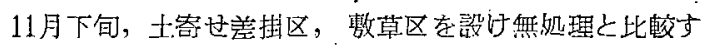

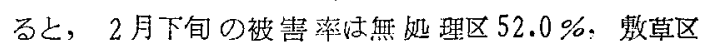
$42.0 \%$ ，士寄せ美掛区16.0\%であり，しかも無処理区は

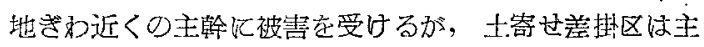
幹には被害少なく，士寄せ部位より露出した枝条の被害 で，教草区はその中間であつた。したがつて土寄せ差掛 がての寒寒予防江有效であるといえよう。

閒い（長嶺）肥料の種類など考えてやつたか。

答え まだやつていない。

問い（長嶺）温度はどのくらいか。

答石 枕崎で $17.4^{\circ} \mathrm{C}$, 知覧で $17.1^{\circ} \mathrm{C}$, 平均気温では あまり差沈ない。極温は枕崎で $4.3^{\circ} \mathrm{C}$, 知監で $-14{ }^{\circ} \mathrm{C}$ 。

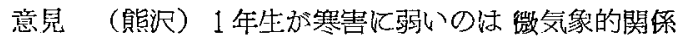
と言われたか゚，“根压の影響もあるようである。粘 士筫よりも軽い土の渒うがひどいようである。

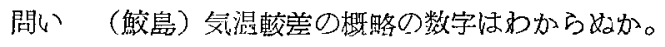

答え 結論を出してないので言えない。

\section{茶樹の凍霜害に関する研究（第10報) \\ 被覆材料，特にかんれいしや被覆の効果について}

農林省東海近畿農業試験場茶業部 高 橋 恒二・青野英也・田.中静夫

䇥瀬好充・吉川茂

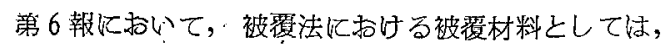
従来用いられていたこもとともに，魚網，玑れいしや

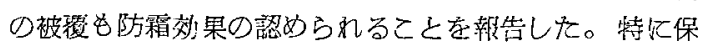

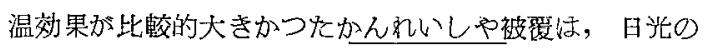
透渦率も良く, 日中被覆の可能性もあるので, 二・三の 網目の異なるかん㣗いしや保温効果と，作業能率の増 進あるいは茶牙の質の向上になる日中被覆の可能性沉つ いて検討した。

実験茶園は当部内の品锤然つみどりを使用し, 本年 4月13〜14日に加けて，1区 $5 \times 5 \mathrm{~m}$ 面積在とり，茶
株上より $60 \mathrm{~cm}$ の高さ江種類の是なるかんれいしき 3 種 と魚縌・上しず・こもを被覆し，露天を含めて計 7 区の 試験区とした。これらの被覆は日中も含めて全日被繁し、 たが，こも・よしずは 5 月4 日まで惊日中取り除き，以 後全日被㠅した。

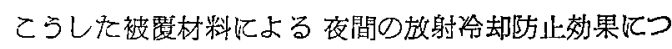
いての調查は，被覆の完了した 4月14日飞行なつたが， 3 種のかんれいしやの中では，綢目は多少あらいが，糸 の太い No. 100 が䒩株上，地表面での保温効果が高く保 たれた。またかん礼しやNo.100 と他の魚網・こもの 


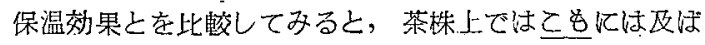
ないものの，刍網化比へて多少骨温飞なつている。こう してかんれいしやの保温效果は，乙もと比較しても多少 劣る程度ですることがかかつてが，その放射冷却防止効 果を気温の画直分布加らみる，露天の株上部の気温降 下に対して被覆区の気温の重直分布は，その温度傾度が ゆるや玑なつている。特にこもの被覆の場合，こもか

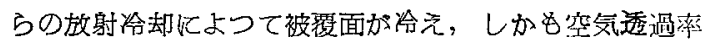
肪悪いため被覆面附近に冷気汃停渄し，より一層冷えて きているが，反面，第一次放射面である地表面からの放 射冷却阻止効果訬非常に良いので，日中被裂によつて地 表面温度は他の被覆区に比べて虫いにもかかからず，被

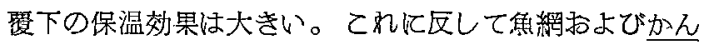
机いしや被覆は空気の透過率が良いために，放射冷却阻 止効果仙こもに比べて劣り，被稪上における二次的逆転 層の形成む少ないように見受けられ，その重直份布は加
なり直線的であるが，魚網被覆では被㣪内飞逆転層の再 形成が見られるので，茶株上気温法汃九れいしや被爱よ り低い場合が多い。

次に日中被㪶した結果について，生育相は露天に比べ

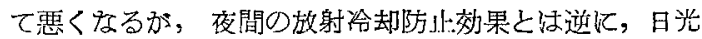
の透過率の良い かん㣗しや・魚綱の生育はこも・よし

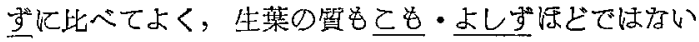
が，露天に比へて向上するので，日中被要の可能性は こもなどに比べてかなり増加するものとみてよい。

問い（周村）気温の低下がある程度を越えると，こ の方法でよいかどうか。

答え一昨年付 $-2.5^{\circ} \mathrm{C}$ までは芽を保護できた。 $-3^{\circ} \mathrm{C}$

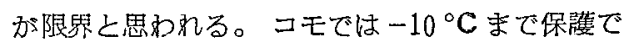
きる。

\section{茶品種の耐寒性に関する研究（第 4 報）}

\section{温度・日長時間が茶品種の生育に及湆す影響と}

\section{それによる耐寒性の変化}

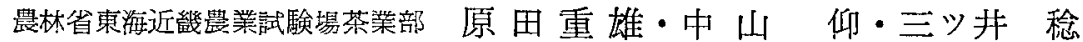

1959年の秋から冬にかけて温度の高低，または日長時 間の長短が，茶品種の生育仅及法す影響と，hardening 効果とにつき調べた。

まず温度の影響㣙ては，五連式亘温装置を用い， 9月21日から11月25日まで, 11品種の鉸植個体を育て, その生育と酎寒性を調へた。その結果は，余芽の生育は

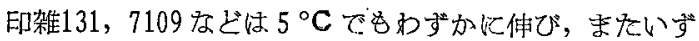
れの品匭も，温度が高くなる洼ど生育が監んですつた。

また，成葉について調べた結果は，低温区渒ど水分含 量が少なく，挨汁屈折率と漫透压が大きく，-5 ${ }^{\circ} \mathrm{C}, 1$ hrの人為低温処理を行ない, その而寒性を比较した結 果は，全品種在通してて各温度区間飞顕著な 被致差が られ，低温区活ど耐寒性が強かつた。そしてかりにー5 C 1 hr 以上の氐温飞耐えるのを, 耐寒性の有無の限界之 すれば， $15{ }^{\circ} \mathrm{C}$ 区では被害を受けない品種がかなりり，

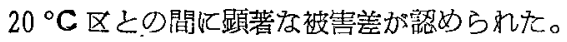

次汇品種間では，印雑 131，7109 の上万に低温でも生 育を続ける品種は新芽はもとより，旧䈎の耐寒性も弱 く, $5{ }^{\circ} \mathrm{C}$ でもかなりの被害を生じた。

しかし，インド種は㥂温では惊とんぞ生育しなかつた

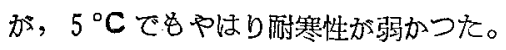

茶品種の耐寒性の宦異に関しては，低温でも生育が進 むため, 耐寒性の獲得の不十分な場合と, 生育は進まな くても耐寒性を十分に獲得できみい場合とがあり，乙れ らの耐性質の组合せによつて, 各品種が種々の期に種 々の酎寒性を示すことが考えられる。

日長効果については，9月 5 日から11月24日までガラ 又空内で 8 時間自然光にさらされ，以後暗幕を的放つて 電登光で， $8,11 ， 14$ 時間の各日長述理を行なつて, 比 较奶照区として，終日自然光にさらした区を設けた。

8 時間区は顕著任生育が抑制され，供試全品種につき 程度の美はあつてもその㑯向はほぼ同梯であつた。

次飞，これらの切枝を用い $-7.5^{\circ} \mathrm{C}, 1 \mathrm{hr}$ の低温処理 を行なつたところ，短日区の活うがやや耐寒性が強い傾 向がみられたが，その差㤝小さかつた。しかし各迈理区 の個体を $5{ }^{\circ} \mathrm{C}$ の恒温ガラス室に入れて 1 週間直てたとて

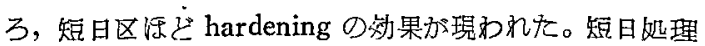

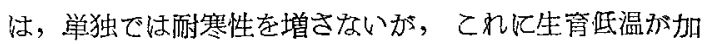
わると hardening 效果を高めることが考えられる。

なお，別绵湯で暗箱をかぶせて短日処㻎を行なつた

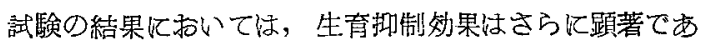
つた。 
問い（植垣）人為低温処理は切枝で行みつたか。

答えしかり。短日処理を行なつたのに低温迈理を加 えると hardening 汃促進される。

問い（高橋）予命をしてか，それともすぐ予定の低 温で処理してか。

答元 最初 $0^{\circ} \mathrm{C}$ 江打き, 次比 $-3^{\circ} \mathrm{C}$ 加ら $-5^{\circ} \mathrm{C}$ 順 次所定の温度にもつていく。

間い（高橋）時間はどうしているか。

答え 上記各温度に20分ぐらいずつるく。とか子をき

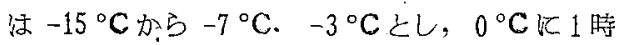
間执く。急に廛らしたり，とかしたりすると被害 が大きい。

問い（安間）沃埸で品種の酎寒性をみる場合，暖地 と寒地で差があるか。
答えしから。同一品種でる寒地では㑬寒性加强いこ と似なる。

問い（植逐）温度に対する変化が 品種によつて異な るだろらと考觉るが。

答え しかり。低温でも伸びる品種は弱い。

問い（鰫島）アッサム染はおそくまで発音するが， 冬期まで生育しているのは耐寒性汃弱儿と考えて よいか。

答え 生育期間は水行が多く，そのため秘括そくまで 伸びること汸附寒性に䇃して不利である。一方冬 期になつて糖分の蓄積が増すととは有利である。 これははつォスフォリラーゼの活力が関与してく るのではないかと思つている。耐寒性の問題に対 してはこのニつの面を考完る必要がある。

\title{
茶品種の耐寒性に関する研究（第 5 報）
}

\section{茶葉のフォスフォリラーゼ活力その他数種の 要因と耐寒性との関係}

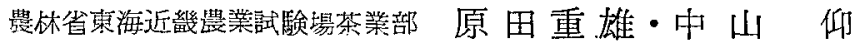 \\ 加納照崇・酒并慎介
}

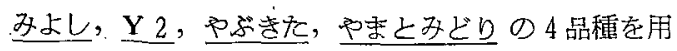
いて，茶葉のアミラーセ，インベルターゼ活力放よび，

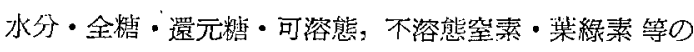
含量と耐寒性との関係沉つき調べた。その結果は，アミ ラーゼ，インベルターゼ活为は附寒性と特期的にも品種 間でも，いずれかといえば負の関保を示した。また，炭 水化物汇ついては，全糖は，㭙期的にも品種間でも，耐 寒性と正の関係を示したが，品種間に夻ける還元糖合量 と耐寒性との関係は明らかでなかつた。
また，峌素化合物については墑寒性との関係が明膫で なく，葉緑素台量は耐寒性之時期的には負，品種間では 正の関係实示した。

なお，炭水化物が全糖とは正の相関関你を示すが，還 元糖とは泌接な関係を示さないととは，別江多数の品種 てつき調べ結果も同様であつた。

な志，別に10㫛種を用い，フォスフォリラーゼの活力 を組織化学的に䛯べ結果は, その活力と耐寒性との間行 正の相関関係が認めら礼た。

\section{茶樹の感温性について}

茶澍の生理和よび生態の温度の変化汇応じたさまざ の動きが発茅・成長・花芽形成・關花・結実 となる。乙 のうち特澍液の流動について調へてみた。

樹液の流動は温度の小昇とともに活発になるが，乙れ
㖘休省金谷茶原種農場 植 坦 敬士

は加温による液汁そのものの胠散性の増大によるか，あ るいは茶街の尌液流動の器関である 維管束組織の軟化か らくる透通性の増大炕よるものであるか，またこの雨者 が相互に作用して生ずるかを明らかにする目的で行なつ 
た。实験方法以近似の睘境で際接した茶園から昨年秋に 出をと思われる新梢を取つて来てガラス空内で暜色液体 を吸収せしめ，上罪して行くのを組織を破壊して測定表 を得た。導管を露出し溶液の着色点之四収口をの間を測 定して上昇值とした。その結果は冬期といえども早朝待

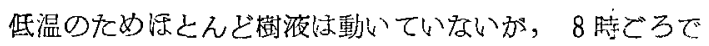

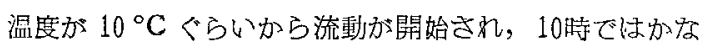
り活発である。12時から 3 時でろまで最高である。午後 は日没とともに低温となるが，2特間余のズレをもつて

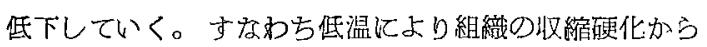

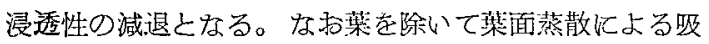
引力を 0 にしたものでの樹液の液体拡散性にの外よると すれ岵, 同一液体では温度の変化による差異は若于は認 められるが，樹液の流動を支配するはど大きな役割は果 していねいようである。

品種では晚生のきまとみ゙り・炏炼まれは感温性が
特ににふくくややふきた・はつもみじは鋭敏であつた。
問い（原田）試験材料に洁根がついているか゚
答觉 贸枝である。
問い（原田）液の上昇する長さを調べたのか。
答え 浸清後 5 分和きに見て 5 個体の平沟をこつた。
問い（原田）浸清するときどんな状態で西つたか。
答㝋 根玨注 0 亿している。
問い（原田）水を上げる力は 葉の蒸散作用の強さに よるが，笨の多少でいるいろ作用がちがうか。
答元しかり。
問い（原田）萊を取り去つた場合は毛細管現象によ ると帣沉らるか。

答え 温度の違い汇よて 毛細管現象も異なつてくる と思5。

\title{
花畫の温度処理と花粉発芽との 関係について
}

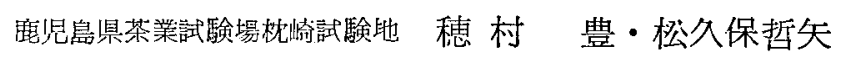

筆者らは昭和33年の本研究発表会に打いて，紅茶㝨の 温湯除雄に関する研究結果（花蕾の温湯処理之花粉発芽 との関係について）を発表した。すなわち温湯除雄の場 合 $45^{\circ} \mathrm{C} の 6$ 分間処理方 紅茶樹の集団除雄队最適の温度 ならびに時間であることを確認したが，実際温湯除雄に よつて人工交配をするに恔，茶澍は本であつて水稻等 とやや挌もむきを異にしている。

開花の幅が広かつたり処理方法に技術的なむづかしさ があつて，集団除雄には不適当であることを痛感した。

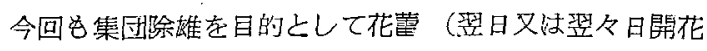
見込のもの）の温度処理を行ない，花粉の発芽伸長を調 查するとともに成刑枝条の乾温による障㫪も調查した。

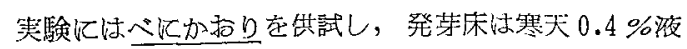
を使用し，空温汇置休，花枌の発芽伸長状況を蚞鏡した。 处理恃定温器で行ない, 処理温度は $30 \sim 50{ }^{\circ} \mathrm{C}$ まで, 処 理時間は 45 分から 12 時間として，温度之時間を組み合わ せて実験を行なつた。

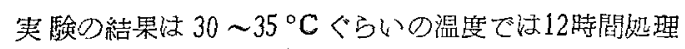
しても花粉得対する影響は全くなく, 発芽・伸長とも標 準之同じく良好である。また $38 \sim 39^{\circ} \mathrm{C} の 3$ 時間, $40^{\circ}$ Cの 1.5 時間の处理でも標準と变らない発芽伸長でする 加， $38 \sim 39^{\circ} \mathrm{C}, 3.5$ 持間; $40^{\circ} \mathrm{C}, 2.5$ 時間; $45^{\circ} \mathrm{C}, 1.5$
時間では少数は発芽するが花粉管は奇形状態を示し，授

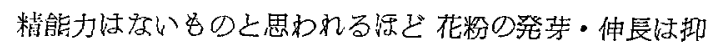
制され辛。

$38 \sim 39^{\circ} \mathrm{C} D 4$ 時間, $41^{\circ} \mathrm{C} \oslash 3$ 跱間, $45 \sim 46^{\circ} \mathrm{C} \oslash$ 2 時間, $47 \sim 48^{\circ} \mathrm{C}$ の 1 時間, $49 \sim 50^{\circ} \mathrm{C} \oslash 45$ 分間で ほ発芽能力は全然なかつた。なかんずく $41^{\circ} \mathrm{C} ， 3$ 㭙間の 处理は花吩の発芽能力むなく，枝条・成葉いずれ《も温 度による障害はなかつた。他の処理温度では長時間を要 したり，あるいは枝条・成葉汇被舂を与えたり, 開花が 遅延する等の結果を得た。

以上の結果を総合すると，乾温による除雄は $41^{\circ} \mathrm{C} ， 3$ 時間が最適であることがわかつた。この㬰験转果を活場 における人工交配に灾用すべく，母澍にビニル被覆を行 ない，天日によつて温度の上昇图り，温度变化を測定 するとともに花粉の発芽能力をも検镜した。垁験は12月 1 日晴天の日を選び行なかれた。温荠変化は $41 \sim 44.5^{\circ} \mathrm{C}$ までの持続時間を 3 時間以上記録した。このうとは窒内

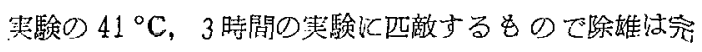
全に行なわれるはずである。ビニル被覆を行なつた母澍 の花蕾を埰取し，花粉の発芽能力を調査した結果全然笄 芽なく，除雄が完全比行なわれたことを磪認した。また 低場のビニル被覆による温度变化を 定温器によつて人工 
的汇造り実験を行つた結果, 花粉の発穿能力は全くなか

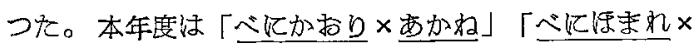
あか格」の2 組合せについで，天日を等源としたビニル 被覆による集団除雄を行ない人工交配を実施した。

ての集四除雄の方法については な找螕多の問題は残さ れている汃，今後さらに研究するてとによつて人工交配 の一方法として確立したい考えである。
問い（鮫島）短時間で高温処理できないか。 答元 高温では成葉に被害があるのでできない。 問い（原田）花粉を低温処理して人為とうたした場 合，それが耐寒性と関係があるか。

答え そういうことはあり得ないかと思う。

\section{改良メタシストックス乳剤による チャハダニ防除試験 特に薬剤の浸透性について}

京都符立茶業研究所 渡辺博 - 加藤尚雄 - 森下富雄

\begin{abstract}
チャハ父ニの防除に政皇メタシストックス乳珴を使用 して，その濃度放よび散布量による防除效果について報 告したが，今回は本凧の浸透性和よび移行力について調 ベた。
\end{abstract}

共試茶樹は和ぐらみどりを使用し，散布濃度は1000倍 㴕とした。

迌理方法:

1 区…古葉全部の䒚表の夕散布。

2 区…古葉全部の葉黄のみ散存。

3 区…荡葉全部の葉表，葉贵峨面散布。

4 区…古葉半行の葉表の子散布。

$5 区$ 区..古葉の湏芽加ら全体の1/3葉までの葉表と，その 葉腋に散布。

6 区…古葉半分の禁兼のみ散布。

7 区…古葉の頂芽加ら全体の1/3までの葉裹と，その葉 腋江散布。

8 区…重散布。

铜查方法 :

各区中，任意に10枝に標識学つけ，その糟示枝の全葉 飞笴生するチャハダ二の咸幼虫数妾調查した。調査は散 布当日, 散有 5 日後, 10 日後, 22 日後, 30 日後の.5 回行 なつた。

\section{試験結祭:}

1 区…殺出効果は散布 5 日後から現われ，最終調查の 1 カ月笋まで生存虫数は少なかつた。

2 区‥1区とだいたい同様の傾向を示した。

3 区…各机理区中最も効果的で，調查日が経過するに
つれて生息密度が潮減し，理想的な殺出曲線を描いた。 4 区…1区よりも殺虫效果は多るよう思われる。

5 区…全調查日を通じて，最も殺虫效果が少つた。

6 区…散有当初の生存虫数むあるが，散布20日得では 最む效果的であつた。

7 区…調查日が経過するにつれて，生息密度が激減の 傾向にあり，相当效果的であつた。

以上の結果から孙て，各好理区とも散有 1 力月得末で 薬丳の效果は認められる。

特に古葉供方して 新葉の生存虫数の少なくなること から考えて，葲液の樹液中の浸透移行力は十分認められ る。

散布後の経過からみて，生存虫数の抑制奻果は相当長 くあると思わ礼るが，殺虫效果としてはあまり長くはな いようである。

な物，新葉と古葉に対する散布の差は，明らかな差は。 認められないが，新葉に散布する乐うが为分良いように 思悋れる。

問い（南川４月18日には牙はないか。

答え一心三葉ごると思う。

問、（南川４月28日に虫がふえたのはなぜか。 答え 理由はわからないか，全体として発生が多くな つた時だろうと思う。

問い（悻川５月には虫は隇つているだろう。 答え そうだ。 


\title{
かまいり茶用品種選抜のための
}

\section{少量製茶法}

\author{
農林省九州礐業試験場作物第 1 部 讃 投 元・中田典男
}

輸出向きかまいり茶用品種の育成を主題にして, 炤和 27年加ら研究火目手しているが，乙の新品種育成の大き なあい路は，少量の生葉で茶品孟の鑑別，検定を適確に

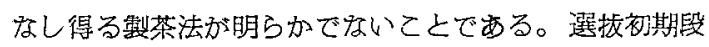
階に品質内容を判定することができれ壮紅茶・愈茶に比 して湿机たかまいり茶品種の裔成を急速に進展させるこ とがでさる。

昭和27年設定したミかまいり茶試験標準製茶法要網、 を中心《して，生葉 $100 \sim 400 \mathrm{~g}$ 孛試料とする製茶法につ

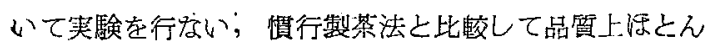

ど差異のない，また多数の個体を容易に処理し得る數法 を明らかにすることができた。

問い（浅田）機械装圆を今後一定にするつもりかど う。

答え 譏械の逊造は今後問題になると思う。

問い（浅田) 試播をさらに少量にしたらどうか。

答え 機械の数造によつて可能である。

問い (桑原) 2〜6 竹でかま香がつくのか。

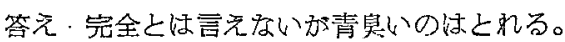

\section{生葉による品質鑑定に関する研究（第1 報）}

\section{かをいり茶との関係}

宮崎県農業試験場川南分場 森哣市二・興梠辰雄

微量の生葉を鑑定することによつて 莱の品買を推定す ることができれば，生葉取引!上の格付け，性質伈念した 榷造上の加隇, 品種育成の期間短樎等化役立つと考元， かまいり菜の関係について試験した結果を報告する。

生葉 $5 \mathrm{~g}$ を英国式審查茶わんで10分間熱湯浸出し, 紅

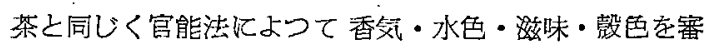
查し，タンニン秙よびアントシアン反広在茶業組合 50 周 年記念品評会成績書に従心調べた。タンニンの監化鉄液 反心深浸出液 $10 \mathrm{cc}$ 共用した。以上の方法によりか

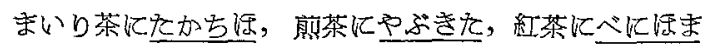

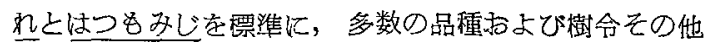
载培環境を舆にした同一品種, ならびに葉位間の品啠差 等につき生葉の品賢を鑑定した結果，個体間の盖は影著 に区別でき，煎茶・加まいり茶・紅茶とそれそれの特徽 を客易化判定できたが，しいて言えば水色の判定が因難 であつた。

水色の判定を容易にするため，生葉を浸出した水色と かまいりに製茶した場合の水色との関係について調べた 結果，生葉を浸出して水色は綠黃・黃綠・黃金・橙黄の 四つに大別され，さらにその濃度により，白つぼい線黄 ・うすい綠黃・綠黃といつた具合に分けられる。かまい り茶として蜼期によつて多少異なるが，愄緣色加白
つね゚い黃金色を中心選べば良いようであつた。またア ントシアンが水色に影響するように見受けられたので, アントシアンの顕著经現われる秋期 (四番茶期) にアン

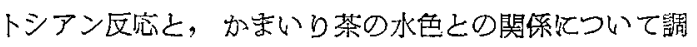
べた結果，アントシアンの特に多いもの(生葉鑑定の反 灾色彩度 3 号以上） は茶の水色が污几た黒味を带びた。 生葉鑑定法汇よつてアントシアンの反応を㤠めるとき は，茶にして 3 号近い反店㑑当するようで西るから， かまいり茶の場合，生葉鑑定で 2 号以下が望ましいよう に思われる。

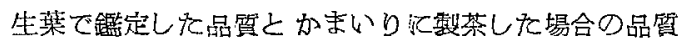
の相関について，一番茶期にた加ちは等19品種, 三番茶

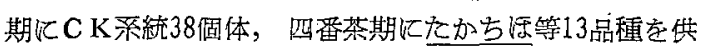
用試験した結果, 相開の有意差も認められた。よつて鑑 定した生葉の品筫加ら，加まいり茶の品望竟推定するこ とが可能であると思われる。

本法は審查茶奻九生葉 $5 \mathrm{~g}$ を10分閒熱楊浸出する簡 便さで，これに熟練す机ば讯速に生葉つ価値を判定でき るので, 生葉筫壳の格付や, 奇種の個体選拢等に役立つ ものと思考する。

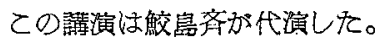




\title{
生葉による品質鑑定に関する研究（第2 報）
}

\author{
紅 茶.との関 係
}

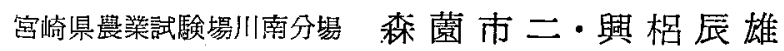

生葉 $5 \mathrm{~g}$ 共用し10分間熱湯で浸出し：その漫出液を 放加まいり茶の品質を推定し得ることを第 1 報で報

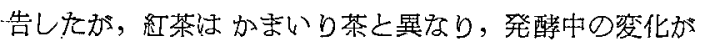

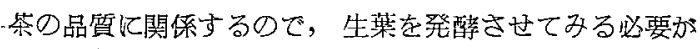
西り，微量の生菜をむつて検定し得る方法はないか人考 え，生葉に水を加えてすりつぶし，その搾汗液としばり 加すを発䤉させ、これを鑑定した品質と，漂凖法による。

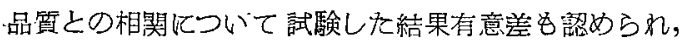
本法（以下「摧汁法」と乎ふ）によつて茶の品質を推定 し得る上思われるに至つたので，こてに報告する。

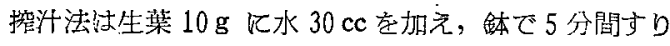
つぶし，その青汗を布でしばり，控汁液 $20 \mathrm{cc}$ としばり 加5 5 内外を得る。しほりかすは 8 号のふるいを通し

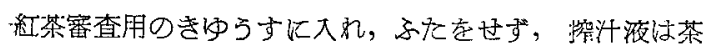

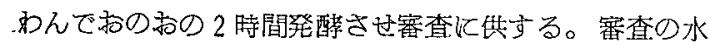
·色之味の鑑定には㩁汁液の上下層をかきまぜ， $5 \mathrm{cc}$ 謇 查茶わえにとり，熱湯 $180 \mathrm{cc}$ 加え希釉して用い，タン ニンの塩化鉄液反応は䆣汗液 $1 \mathrm{cc}$ 走供し, 第 1 報之同し 万法により調へた。香気之設色は発醉させてあつたきゆ うすに所定の時間 (2 㭙間) がきたら，ふたをして普通

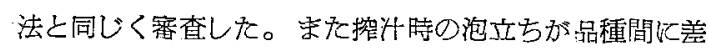
が大きいように胃受けられたので，控汁液 $5 \mathrm{cc}$ を試験管 に取り，1分間 160 回上下にふり，泡を立てて10分静置 传泡の高さを測つた。標準法怯生葉 $100 \mathrm{~g}$ を $30 \mathrm{~cm}$ 角の 金あみに $15 \sim 18$ 時間自然萎调し，萎调の程度は一番暴で $38 \%$ ，夏荣で35\%とした。すりつぶし始めてから 2 時間 発䤃し審查に散した。審查は常法に证つた。

以上の方法により1958年の三番茶期と四番茶期飞， ペ
に底ま社等20品種を供用し，また1959年の二番茶期に，

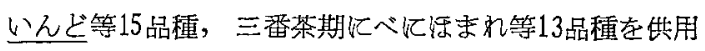
し，撚汁法之標準法について比較した。搈汁法はすりつ ぶした青汁をしぱるときでに汁溜の色や，泡立ちが品 種間㦈異が認められ，時間のたつに従い発醉がどんど ん進み，ひいては発酻過度の現象を現わした。発醉は 2 特間を適当と認め，2 時間汇統一した。抬汁法による鑑 定の結果と䏇㔼法による鑑定の結果を，鑑定した項目こ とにその相関を求めた結果，有意恙も認められた。よつ て搾汁法により鑑定し飞品質から茶の品質を推定するこ とが可能であると思われる。

本法によれば，生葉 $10 \mathrm{~g}$ といら微量でしが萎调を必 要としないから， 2 時間後には結果が判明し茶の品質を 推定されるから，生葉の格付や育種の個体選拢等侸役立 つものと思考する。

この講㴼は鮫島斉が代演した。

問い（大岛）水色，香気など数值的火求められない ものの相関を考えるととができるか。

答え 審榃俨点によつたが，品質と何か関係がでそう ぞと思つてやつた。

意見 (大島, 鳥井) 審査評点の等間隔性しいうこと にも問題であるか゚，製品の審查では従来一沁の基 售はある。しかし生葉の蜜査はいままでやつたて

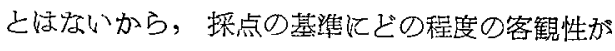
あるか，簡単に評点が付けられないように思う。

意見（古谷）順位でやれ机相関が出せる。

\section{茶貯蔵における温度および水分の 影響について}

睠林省東海近畿農業試験場茶業部

茶眝蔵に和ける温度和よび 水分の影響を明らかにする ため，1959年一番茶期の愈茶を用い，水分を 3.7，5.7， $7.5 \%$ とし，乙礼を低温 (約 $5^{\circ} \mathrm{C}$ ), 常温 (平均気温 18～ $26^{\circ} \mathrm{C}$ ), 高温 (約 $38^{\circ} \mathrm{C}$ ) 飞 2, 4 力月館藏し, 品質, ビタミン $\mathrm{C}$ 残存率，浸出夜の巴の变化などを調べた。
古谷弘三・原利男・久保田悦郎

実験結果を要約すると次のとおりである。

1. 低温に貯藏した水分 $5.7 \%$ 以下のもの之，常温に

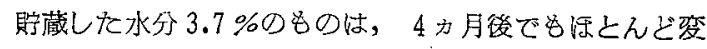
質江認められなかつた。またてれらのものは 4 カ月後で もビタミンCは70\%以上残存していた。 
2. 常温飞眝蔵した水分 $7.5 \%$ ， 高温に貯藏した水 分 $5.7 \%$ 以上ののは，2 月月後で非常に変賴してい た。宋たてれらのもの注 4 カ月後でもビタミンCの残存 率か5 $50 \%$ 以下となつた。

3. 水分 $3.7 \%$ 亿䫧燥した茶でも，貯葴温度 $38^{\circ} \mathrm{C}$ で は，その変質注防止できなかつた。水分 $7.5 \% 08$

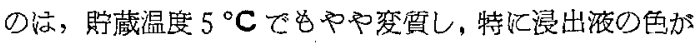
変化した。

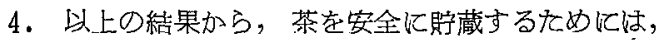

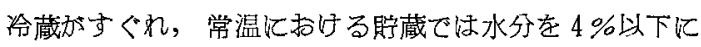
保たなければならなかて。

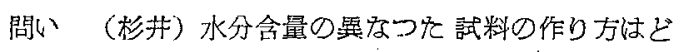
うするか。

答元 最初 $3 \%$ のの作り，乙肌を四湿させて水分

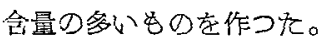

閏い（杉井）水分含量の多いものから，少ないもの を作つたときと違いはないか。
答え やつてないから何とる言えない。

問い（岡野）1コの共試料はどのくらいか。

答无 1/2ポンドに入れた。

問い（凧野）かん化入れる量比よつて違いはない 加。

答え がん詰ではその点あまり考える必要はないと思 う。

閶い（浅田）ヘッドスペースの多少でふれがないだ ろうか。

答え 大量の容量と小量のものでは，やつてみなけれ ばわからないか，感じでは变らないのではないか と思う。

問い（鳥揞)良, 不良のきめ手は何が。

答え 順位の合計の羑で良, 不良を区別できる。

問い (鳥井) 奶にした 2 個の良, 不飠の判定ではな くて，変躓したかせぬかの判定はどうするか。

答えVCの残存率 $60 \%$ 以下のものはだいたい变質し ているとみなしてよい。

\section{萎调中の温湿度と萎调速度, 品質との関倸 (との2)}

\section{農林省東海近畿農業試験嚗茶業部 桑 原穆夫・竹尾忠一}

佐藤哲哉・古烟 哲

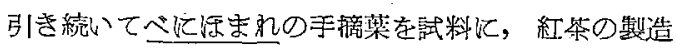
上久くことのできない萎淍条件について，亘温佰湿器を 使つて温湿度を下表のように変化させ萎调速度, 茶葉

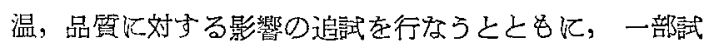
験でポリフェノールオキシダーセの力価，摘芽部位別の 荌凋速度の差も検定した。

\begin{tabular}{|c|c|c|c|}
\hline 温繁 & & & \\
\hline $20^{\circ} \mathrm{C}$ & $\overparen{40 \%}$ & $60 \%$ & $80 \%$ \\
\hline 30 & 40 & 60 & 80 \\
\hline$A 0$ & 40 & 60 & - \\
\hline
\end{tabular}

萎调速度については，試料の都合でその装入量を減ら

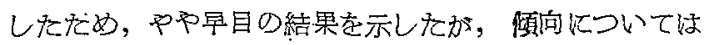

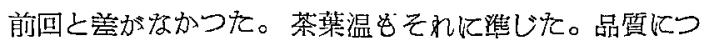
いては水色が $40^{\circ} \mathrm{C}$ 区は濃いため良く判定さ㣗，200
区は薄いので格落ちし，その差を有意としたが，その质 かの項目では瑟唯められなかつた。ポリフェノールオ キシダーゼは， $30^{\circ} \mathrm{C}$ で湿度の変うた例では，湿度の高 いものの恬うが力価は高かつた。このポリフェノールオ キシダーぜは，前回 $35^{\circ} \mathrm{C}$ になると正常な発酵が阻害さ れるように報告したが, $40^{\circ} \mathrm{C}$ の例でる茶集温は $35^{\circ} \mathrm{C}$

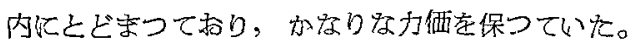

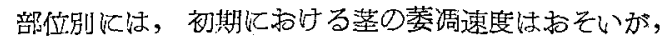
時間の長い場合，その萎凋率の違いは缩末る傾问を示し た。最も早く萎凋し，萎调率の高いのは1葉で，3葉は 萎调しにくく, 巷鼡率も最も低かつた。

閩（鳥井）萎凋率とは何加。

答え 重量減をさす。 


\title{
茶葉の乾燥機構に関する研究（第3 報）
}

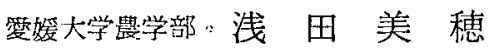

前回の計量装置孛政良して，30 160 ${ }^{\circ} \mathrm{C}$ の䦰で器 内温度・重量娍・葉内温度・时刻 94 種息自動速続的飞 電磁オッシログラフ 用印画紙汇点綴記録せしめを結果, 斾回までの成績とよく合致するつを認わた。よつて前回 の記録上ともに各種変換点吟味し $b, c, c^{\prime}, f$ 曲線を 得た。さらに $80^{\circ} \mathrm{C}$ 以下で変色状態䒚肉眼で観察し，变 色の開始, 終了時間を测定して限界線 $(\mathrm{H}, \mathrm{I})$ を, ま

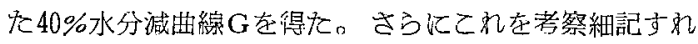
ば，

（1）低温の場合，すな膈ち約 $35^{\circ} \mathrm{C}$ 以下，H曲線儿触 れないときは変色することなく萎调の目的存達せられ る。

（2）彷来の人工萎调比いては相当な高温風（40５０

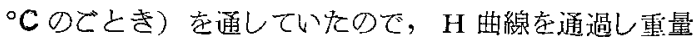
減 $40 \%$ 線一G一汇達しているから，色沢・香味が自然萎 淍のときと翼なつた状態として兒われるので留意を要す る。

（3）さら江葉買に損慯を及ぼすような操作は変色を促 進させるから，萎调中に括いては避けるべきである。

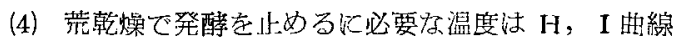
より高温度の $90^{\circ} \mathrm{C}$ 近くでなければならないことがるか る。

\section{紅 茶 工}

線茶製造厂場設偳については昭和の初期筆者の提唱以 来，ほぼ合理的炕規格化普及されているが，龽茶の日本

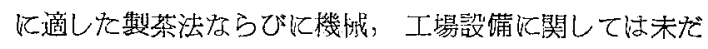
確立されず多くの検討事項を残している。筆者はマライ

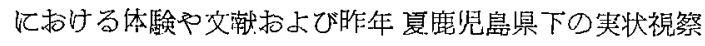
等汇より，また「茶葉の乾炶機講」中 $100^{\circ} \mathrm{C}$ 以下紅茶

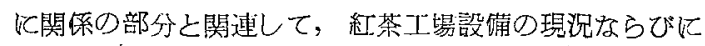
改良案の一部走得たので発表する。

萎 绸

(1) 方法の現说：自然萎调（40\%水分滅漂集）在主之 するも，広い窒と長い特間（12〜20時間）を要するので

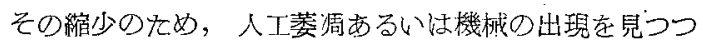
每る。
(5) $80^{\circ} \mathrm{C}$ 以下の相当高温度でも時間が短い場合，す なわちH曲線炕達するまでにとどめ，急冷してさらに前 回以下で加温して H曲線に達せしめない方法を繰り返し

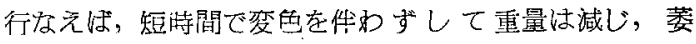
淍（40\%重量減を瞟準とする）の目的を達子られるとは 必すしも断言できない。

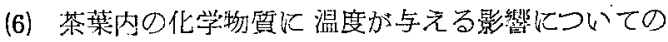
研究は前行して行なわ礼，相互交流して正確汇諸变化の 移行を表現することが望末しい。

(7) 以上に哭连する事項として次の昨究を進めつつあ る。

(i) $90^{\circ} \mathrm{C}$ 以上飞打りる $\mathrm{b} ， \mathrm{c}$ 線の究明は，(ii)之とも に熱風蒸し，およびかまいり茶の製法江重要な関係をも つで車万弓。(ii) 鮮緑になり始力る特間对温度曲線一J 絴線になり切つた時間対温度一K一を究明すれば，この 両曲線の囲む籍囲は蒸しの研究の対照として役立つであ ろう。(iii) $160^{\circ} \mathrm{C}$ 以上綠绝を損じ始少尚時間対温度曲線 一L一，黑褐色になつて岸化を現わすまでの㭙間対温度 曲線一 $M$ 一等は漂うじ茶㹕法走唆するものと考える。

図表比ついて本，久保田から質閯があつたが省略す る。

\section{場設備}

\section{悪媛大学農学部 浅 田 美 穂}

(2) 設诵の現況：ヘシャンクローズ $(1 \times 5 \mathrm{~m})$ 〜 $20 \mathrm{~cm}$ ことに10 11段重畳 2 列に接近架設し，それい $500 \sim 700 \mathrm{gr} / \mathrm{m}^{2}$ 亿余葉を散有して，生産量に応じそ広い 娄调空を 2〜3階に設けて自然萎调し，あるいは乾燥機

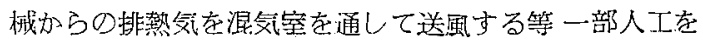
加えている。しかし通気状沅は各段各所不均等が多く萎 调をらを生ずる欠点を倠つている。

(3) 改良案 : (a) 混父室飞排風機の半数を移動し送 蚛機として取り附ける。(b) 乾燥機加らの熱排気を中央 罗入口汇導き，(c) 高温汇失するときのため排出管を設 け，(d) 空外の冷風方るい後方加ら一循環した空気を 再び吸入する管あるいは導入部を作りダンバーで調節

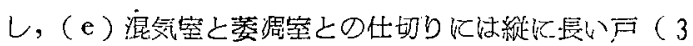




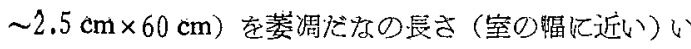

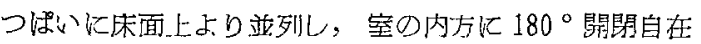
飞取り附け，(f) 湜気室側へ上下娚節ができるよろい戸 を附けて風向・量・速さ調節过る。(g) 混曶空と反対

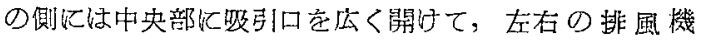

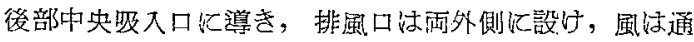
路を逆流し湿気室の禹側䏦加ら混気送風機の後部中央吸 大口に通ずるよう困う。(h）要すれば採光用横密之上部

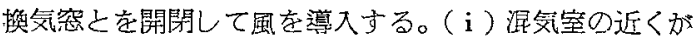
早く萎调する扣とれがあるときは生葉の散布と取出しの 順序を考流る等のことにより，萎 绸度の均等化を計る。

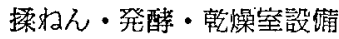

(1) 現況と政良方針：この3空を共通化した例がまま あつたが，近頃ではそれぞれ仕切ることを獎励されてい

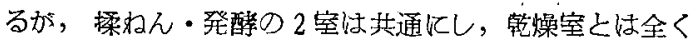

仕切る加息心。

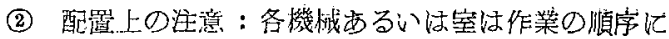
往つて製品汃最短距離（值線的）に進行して，必要な時 間飞次へ到達するでとくにし，交差，逆行せぬように注 意して配列する。

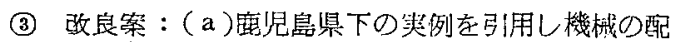
置を二，三变えることによつて，ずつと墈きやすい工場

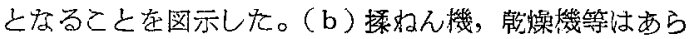
かじめ䛅画された向きに摘合するよう右勝手するい性左

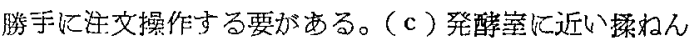

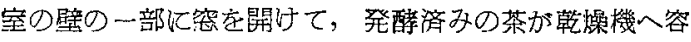
易に送られるように設满すると便利である。

希望 (大島) 既設の工塨にとらわれない独創的な設 計も扮願いしたい。

\section{花粉フラボノイドIについて}

鹿、兒島県茶業試験場枕崎詿験地 坂本裕

著者がさきに，茶花粉から分㒕したフラボノイドாは 鮮黄色，きかめて水溶性で，㙁酸マグネシウム反応，智

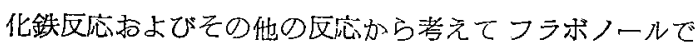
西ると考えられたが，既知の荣葉フラボノイド類とは異 なつたものであると推定された。

これを $2 \%$ 硫酸で加水分解すると，アグリコンが約

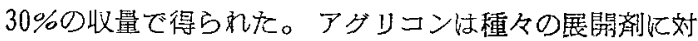
する $R f$ 值がケンフェロール沉きわめて近いが，紫外線 下の䖝光から，ケンフェロールでないことが判明した。 よつて先にケンフェロールと報告したのは取り消した い。

九大，大島博士ならびに䣄䥾氏をわずらわして得られ ネアグリコンの分析結果标次のと晾りであつた。

紫外線吸収スペクトル：スペクトルの山は273，326， $375 \mathrm{~m} \mu$ 飞あり，水酸化アルミニウムの場合は $435 \mathrm{~m} \mu$ K ある。この結果功つラホノールであることは間違いな い。

元素分析：C $59.77 \%$ H $5.44 \%$

$$
\mathrm{mp}: 248^{\circ} \sim 250^{\circ} \mathrm{C} \text { (昇華あるいは分解) }
$$

アセテート：光輝ある無色の長針晶 $\mathrm{mp} 157 \sim 158^{\circ} \mathrm{C}$

アダリコン体で，乙の mp 飞相当するものは未だ知

られていない。

アグリコンはレモン黃色の薄い板状結晶で，エタノー ル, メタノール, 熱水, 水酶, ピリジン飞溶け, 塩酸一 マグネシウムで桃紅色，㛺化鉄で法污黄色，紫外線下に
暗監色の營先，これにアンモニアガスを当てるとさえな い綠黃色儿变ずる。花粉抽出波から中性酷酸鉊で沈殿す るが，このものの水溶淮は塩基性酰酸鉊からレモン黄色 の沈殿上なる。

グリコシドはきわめて水溶性であるところから，糖の 数も多いものと推定される。グリコシドを加水分解する 之前記の之拉り，30\%の収面でアグリコンが得られた。 その口矿につき, SOMOGYI法により還元焙定量を行なつ t。

$$
\begin{array}{ccc}
*=\left(0.005 N, \mathrm{Na}_{2} \mathrm{~S}_{2} \mathrm{O}_{3} \perp \mathrm{cc}=0.145 \mathrm{mg} \text { として }\right) \\
\text { グリコシド } & \text { アグリコン } & \text { 糖 } \\
24.26 \mathrm{mg} & 7.3 \mathrm{mg} & 16.51 \mathrm{mg} * \\
100 \% & 30.09 \% & 68.05 \%
\end{array}
$$

すなわち，グリコシドはアグリコン $30 \%$ ，糖部約 70\%の割で結合しているものと考えられる。

炶のペーパークロマトグラフィー，一次元，二次元， 多重照憵法を用い，呈色剂むアンモニア性硝酸銀，アニ リンフタール酸, レソルシン塩酸, $P$-アニシジンリン 酸, フロログルシン・トリクロール醀酸, ベンチジン-醀 酸等の多数を使用して糖の定性を行なつた。その結果判 然と倠認されたものは，ラムノース，フラクトース・グ ルコースであつて，その他ガラクトーズの存在が推定さ れる。また呈色の強さ，スポットの大きさから推定して

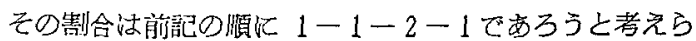
れたがさらに獏討して確認したい。 
花粉フラボノイド【は最初，受掅機構に関保があるか 否かを知るために研究を開始した。すなわち受精の際，

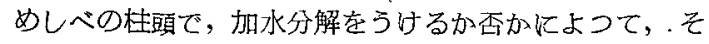
の成否に関与するものと推定したのであるが，今回の害 験加ら，めしべによつて分解されないことが罀めら れた。またフラボノイド在伐つて各種花粉管の発苝率 および伸展度を険討したので，その結果もあるせて垠告
する。

問い（大區）試料の花狢は品種の混合したものか。

答え 分竅に使つたすのは湿合しているが，個々の品 輜の花粉を調べた結果ではだいたい同じで，在来 種が最も多く、アッサム種は少なかつた。交配種 はこの中間䏓すつた。

\section{カフェインの微量定量法}

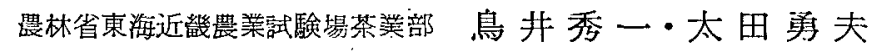

さきに演者らは GROSSFELD-STETNHOFF 法を歌めて, 試料は従来法の1/6, 所要時間を1/2以下に短縮したカフェ インの少量定量法と，その装置を考案した。今回は光電 分光々度計でカフェインの紫外部吸収を測定して, さら 飞微量の定堛法の設定を企てた。

カフェインは口紙電気泳動法により分離し，紫外線照 射によつてスポットの位置を知り，乙の部分の口紙存切 り取り，クロマトグラフィの下降法沉準じたす法で温湯 による抽出を行なつて可橹液を作つた。

カフェイン水溶液の紫外部吸收曲線は $272.5 \mathrm{~m} \mu$ 江最 大吸収を示し，305 maでは吸収は認められなかつた。な

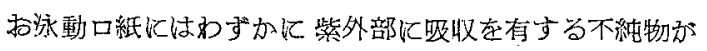
あるので，口紙片の温水抽出波で吸収曲線を測つたとこ

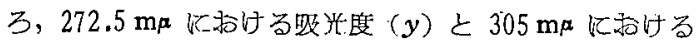
吸光度 $(x)$ との間飞次の回厝式が得られた。 $y=1.63 x+0.00361$

それで可㛟溜の $272.5 \mathrm{~m} \boldsymbol{\kappa}$ と $305 \mathrm{~m} \boldsymbol{\mu}$ の西光度を測り，
後者はもつぱら不紟物代基づく吸収であるから，上式か ら $272.5 \mathrm{~m} \mu$ Kおける不純物の吸洸度を求め，乙れを可

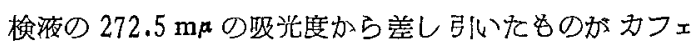
インの哗光度になる。これを次のカフェインの検量曲線

$$
\begin{aligned}
& y=20.3 x \\
& y: \text { カフェイン濃度 } \mathrm{ppm} \\
& x: 272.5 \mathrm{~m} \mu \text { の吸光度 }
\end{aligned}
$$

代入してカフェイン量索求める。との上う化して求め

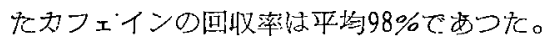

次に現行法との比耪を行なつを結果, 11回の反覆で現 行法之新法の平㚬值および CVはとれぞれ 4.10\%，4.07 $\% ; 0.80 \% ， 1.37 \%$ あつた。

\section{問い（大島）使用した口紙は何か。不純物はあらか} じめ口紙在洗浄すればとれないか。

答え 口縟は果洋 No. 50 で，洗浄の姆果はあまりな かつた。

\section{茶園に水ける土堙水分の年週 変化について}

浆林省東海近畿農業試験場茶對部 河合惣吾・森田昇

雪気抵抗式土垷水分計を使用して，茶園の土壇水分の 年週变化を明らか纪ようとして，1958年 9 月から1959 年 8 月まで，幼木園（定植後 2 年，卧とえど裸地纪近い もの）之成木園（樹命20年）の表・下留上:石骨ブロッ

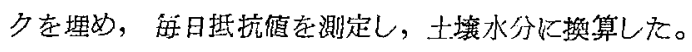
その結果・

表層の土壤水分：奶木園ではそのときどきの気毁条件
とくに降雨の状況に大きな影響をうけ，規則的な变化を 求めるのはかなり困難であるが，一般的に冬季と夏季に 減少が著しい。成木園では冬李にわずか汇減少の傾向が みられたが，大幅な変化は㾜とんどない。

下層の土銥水分：表層土湶ど著しい変動はないか，幼 木園, 成木園とも冬季 (12月～3月) 飞減少する。とく に幼木橉では夏季の $50 \%$ 近くに隇少する。 
このような結果は，土壌水分の変動が主として二墡表

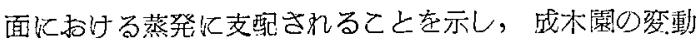
が，表・下層上ともきわめて少㧅のは，う坟間が莱徽

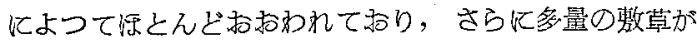
施用されているためであるう。しかし，電氮抵抗土噀水

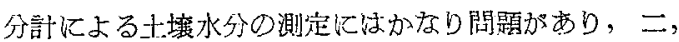
三の䈝点と補正の方法を提案する。

\section{問い（前原）水行計の洒格恃何程加。}

答え 3万円，ブロックは35円。

問い（桴瓜）ブロックの大きさ。

答え $3 \times 6 \mathrm{~cm} く$ くい。
問い（前源）ブロック在埋めてからどのくらいの㭙 間で平衡飞達するか。

答元 3 時間ぐらいかかる思う。

問い（橋瓜）水分変化は土壤の種類によつて閧なる と思うがどうか。

答え 今後の検討が必要であるが，如そらく異なると 思う。

問い（前原）深い所は水分变化が少ないと言つたが 摘採の影響はないか。

答え そんな微妙なものはこの梁さには影響しないと 思う。

\section{茶園土堙における石灰窒素 の分解について}

農林省東海近畿農業試験場茶等部河合物吾・高柳博次

石灭窒素は土壤中において，その主成分であるシアナ ミッド態窒素が アンモニア態や硝酸態に分解して茶澍に 吸收されるものであるが，この分解は一般に土境水分・ 酸化還元状態・地温・土䨘・土壤反忍・施用量 あるい得 土壤との混和度によつて異なるといわれている。われわ れは强酸性下の茶園土壤の改良策として，石网窒素の施

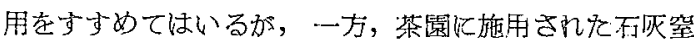
素の分解状況を検討して括かをけれは，合理的な施用法 を講ずることはでさない。かかる意味で石灰窒素の分解 とこれに関与寸る諸条件について追求中でするが，今回 はこれまで行なつた結果の一部を報告する。

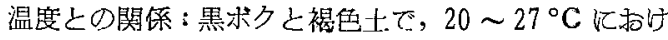
る場合のシアナミッド態窒素の份解 状況を謂べたとこ

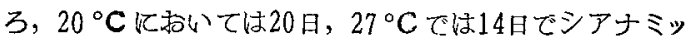
ド態窒素は全部分解した。

土壤水分との関係 分を最大容水量の $50 ， 80 ， 100 \%$ として，それでれシア ナミッド態窒素の分解を調ベたところ，両土壤ともに50 \%の水分舍量の場合, 分解が最も息好であつた。

土壤つ種類との関倸：火山灰采・黑ボク禾・褐色上婪 の茶園土壤を用いて，シアナ゙ミッド態輁素の分解状況を

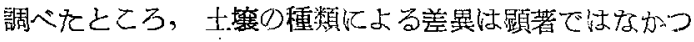
た。

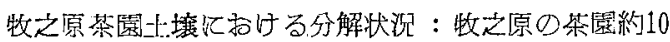
点の土墥を用いて、シアナミッド態窒素のアンモニア態 和上び硝酸態への移行状況を調ベとところ，いずれの土。

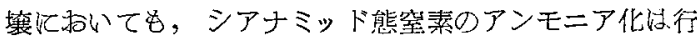

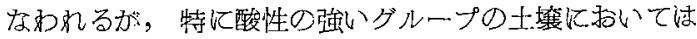

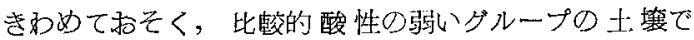
は，このアンモニア化は 前都に比してかなり早いことが 認められた。

さらに硝酸化纯きわめて微弱で，いずれの土壤におい ても，棌としどその生成がみられなかつた。この原因の 一部は，石灰空素のいわゆる硝化作用の狮制尤るもの と推察されたので，尿素を用いて同様な試験空行なつた ところ，はをして，石灰窒素の諹合比して㞗素では， この艄化作用がやや胿盛であつた。

問い (前原) 茶尌はアンモニア態と硝酸熊といずれ を四収するか。

答元いずれも吸収する。

問い（前原）黑ボりは火山灰土上違うのか。

答え ここで言うすはは山灰土に類似しているが, 牧 之原の黑色土壤のことで，有機買の非常に多い土 である。 